\title{
INSTRUMENTS FOR SUPPORTING MEMBERS OF THE EUROZONE IN OVERCOMING FINANCIAL CRISIS UTILISED BY THE INTERNATIONAL MONETARY FUND USING THE EXAMPLE OF GREECE
}

\begin{abstract}
The purpose of this article is to present the instruments and resources used by the International Monetary Fund to support the euro area countries in overcoming the financial crisis on the example of Greece. The article points out types of loan instruments and other measures taken by the IMF to support Greece. The author also indicates the reforms that had to be made at the IMF for a better and more efficient operation of this institution against the challenges of the global crisis. In addition, the specificity of cooperation between the IMF, the European Commission and the European Central Bank is analyzed.
\end{abstract}

Key words: IMF, financial crisis, international financial obligations, European Stability Mechanism, EU

* Department of International and European Law, Cardinal Stefan Wyszyński University (UKSW) 


\section{IMF Goals and Objectives}

The International Monetary Fund (IMF) came into existence during the United Nations Monetary and Financial Conference in Bretton Woods in June 1944. The International Bank for Reconstruction and Development came into existence in parallel with the IMF. The establishment of both institutions was preceded by discussions of politicians and experts on how to rebuild the world after WWII and the possibilities of giving economic aid for the development of the world and creating mechanisms to overcome economic crises (bearing in mind the experiences of the Great Depression) ${ }^{2}$. The IMF is a specialised organisation within the United Nations (UN) ${ }^{3}$, it is a legal entity ${ }^{4}$ and has an independent management personnel and organisation structure from the $\mathrm{UN}^{5}$. The members of the IMF are almost all members of the UN. However, members of the IMF are not automatically members of the UN; certain conditions have to be met, found in the Articles of Agreement of the $\mathrm{IMF}^{6}$. At present, the IMF comprises 189 members $^{7}$. The rules of the IMF, how it functions, its purposes and objectives are defined in the Articles of Agreement of the IMF. Article I of the Agreement defines the six purposes of the organisation. Its first purpose is to promote international monetary cooperation through a permanent institution which provides the machinery for consultation and collaboration on international monetary problems. The next purpose highlights the general expected direction of the development of the world and world economy through the facilitation of the growth of international trade, high levels of employment and real income. The third purpose of the IMF is the creation of a system of stable exchange rates and orderly exchange arrangements among members. Purpose Four concerns the next

2 P. Gąsiorowski (ed.), D. Frankiewicz, M. Grotte, A. Życieńska, Międzynarodowy Fundusz Walutowy w reakcji na światowy kryzys finansowy i gospodarczy, https://www.nbp. pl/badania/seminaria/20xi2012.pdf, accessed on: 22.02.2018, p. 2.

3 Funds, Programmes, Specialized Agencies and Others, http://www.un.org/en/ sections/about-un/funds-programmes-specialized-agencies-and-others/, accessed on: 22.02.2018.

4 Article IX, passage 2, Articles of Agreement of the IMF (M.P. - Official Gazette of the Republic of Poland - 2010 No 36 Item 501).

5 Article XII, Articles of Agreement of the IMF (M.P. 2010 No 36 Item 501).

6 Article II, Articles of Agreement of the IMF (M.P. 2010 No 36 Item 501).

7 The IMF at a Glance, http://www.imf.org/en/About/Factsheets/IMF-at-a-Glance, accessed on: 3.05.2019. 
part of creating a common global economic system and the development of trade through the establishment of a multilateral system of payments in respect of current transactions between members and in the elimination of foreign exchange restrictions which hamper the growth of world trade. This purpose highlights the need for the development of mutual trust between members. The fifth purpose concerns one of the most important objectives of the IMF - supporting members through a system of loans and guarantees whose aim it is to correct maladjustments in their balance of payments. It is worth mentioning that Purpose Five also mentions the fact that any support offered by the IMF can only be undertaken under adequate safeguards. This is the basis for the conditions set by the IMF, the undertaking of reviews and the realisation of its supervisory authority. Purpose Six directly corresponds to Purpose Five and concerns the elimination or minimisation of the disequilibrium in the international balances of payments of members. All actions undertaken by the IMF must be in line with the purposes set out in Article I, that is contribute to the stabilisation of exchange rates and the exchangeability of currencies, which will lead to the growth of trade between countries and to the growth of the global economy. The management of international trade as well as the issue of currency rates is strictly correlated with the question of the balance of payments and therefore the IMF supports member states in overcoming problems related to maintaining the stability of the balance of payments.

Over the years, the IMF has undertaken a series of activities aimed at realising the goals entrusted to it by its members. The general goals need to be backed up with concrete actions. These actions can divided in terms of their functionality: financial aid and expertise (advice for political decision-makers from particular countries as well as the exchange of knowledge and experiences). The IMF provides aid through loan and liquidity instruments according to specific rules to countries that have problems maintaining stability in their balance of payments. However, the granting of loans is strictly connected to receiving expertise and recommendations on essential steps to be taken by the country in question. The granting of loans is always connected to the requirement to introduce reforms by the member state, loans are provided in tranches of which subsequent tranches are dependent on undertaking necessary repair activities and the introduction of appropriate reforms. According

8 Article I, Articles of Agreement of the IMF (M.P. 2010 No 36 Item 501). 
to data presented in March 2019, the IMF had USD 1 trllion at its disposal for loans. Other than its role in granting financial aid, the IMF has also developed its role in providing expertise, consulting and supervision, which can be found, other than in the advice provided to borrowers, in the preparation of detailed analyses, reports and studies on the global economy and particular member states ${ }^{9}$. The preparation of reports by the IMF is of considerable significance for the functioning of modern trade as well as for decisions taken by particular countries, international as well as regional organisations ${ }^{10}$.

Achieving the goals set by the IMF is only possible through the involvement of and cooperation with particular member states. Article IV defines the basic responsibilities of each member. Countries are obliged to have an economic and financial policy geared at economic growth whilst maintaining price stability. Countries are obliged to refrain from the manipulation of exchange rates or international monetary systems. The actions of states should bear in mind cooperation on building a transparent, stable system of trade and stable exchange rates. In connection with the adopted obligations, members have entrusted the IMF with supervision over international monetary systems, which implies that every member must fulfil the obligations stemming from Article IV ${ }^{11}$. The supervisory function of the IMF is based on the Articles of Agreement of the IMF, however particular frameworks and forms of supervision are defined in decisions published by the Executive Board of the IMF, the basis of which is found in three documents: the "1977 Decision on Surveillance over Exchange Rate Policies", the 2007 "Decision on Bilateral Surveillance Over Members" and the 2012 "Integrated Surveillance Decision". The last decision published by the Executive Board is its reaction to the financial crisis and a rebuttal of accusations made against the IMF that it did not foresee the financial crisis in time and that its supervision was fragmentary and did not take into account the possibility of problems appearing on a global scale and the fact that the economies of particular countries and regions were having an effect on each other ${ }^{12}$. The supervision undertaken by

9 The IMF at a Glance, http://www.imf.org/en/About/Factsheets/IMF-at-a-Glance, accessed on: 3.05.2019.

10 See more: IMF Publications, https://www.imf.org/en/publications, accessed on: 3.05.2019.

11 Article IV, Articles of Agreement of the IMF (M.P. 2010 No 36 Item 501).

12 P. Gąsiorowski (ed.), op.cit., p. 4-6. 
the IMF can be divided into three categories: (i) supervision over particular countries, (ii) regional supervision and (iii) global supervision. Supervisory reviews over countries are undertaken by the IMF periodically. A team of experts from the IMF working within the scope of the supervisory authority granted to them by Article IV of the Articles of Agreement of the IMF visits a particular country, evaluates the development of its economy and finances, and it also has conversations about the country's economic and financial policy with government officials and representatives of the banking sector. IMF officials often meet with parliamentarians and business representatives, trade unions and civil society. Regional monitoring involves the IMF undertaking research into the monetary union policies of the eurozone, the Economic Community of West African States, the Economic Community of Central African States, and the Eastern Caribbean Currency Union. Regional economic forecasts are the basis for discussions on economic growth and key political issues in the regions of Asia and the Pacific, Europe, Near East and Central Asia, Sub-Saharan Africa and the Western Hemisphere. Global supervision seeks to identify and track trends in the global economy. The primary forms of this type of supervision are manifested in the preparation of reports, amongst others, World Economic Outlook, Global Financial Stability Report, and Fiscal Monitor. These three reports are published biannually with updates provided every quarter. Furthermore, the Board often holds informal discussions on global growth of the world's economies and markets ${ }^{13}$.

The actions undertaken by the IMF often meet with criticism. Even before the global financial crisis struck, the IMF was accused of imposing a liberal vision of economic policy, which was not an adequate solution for some of the countries applying for IMF aid ${ }^{14}$. After the global financial crisis, the IMF was accused of not implementing suitable actions in time which could have warned countries about the crisis or minimised its consequences $^{15}$.

13 Surveillance, https://www.imf.org/external/about/econsurv.htm, accessed on: 20.03.2018.

14 Unwanted Saviours. Criticism of the Actions of the IMF and World Bank has surprisingly Strong Foundations, http://bit.ly/priel-18-2-9, accessed on: 11.03.2018.

15 P. Gąsiorowski (ed.), op.cit., p. 5-6. 


\section{Actions undertaken by the IMF in Answer to the Global Financial Crisis}

The financial crisis caused a variety of problems in the functioning and solvency of institutions within the financial sector and in the longer perspective disruptions in the balance of payments, economic and monetary systems in the countries in question. Intervention actions were undertaken by particular national and international institutions. On the level of the countries in question, these actions were taken by the central banks; on the level of the EU these actions were taken by the European Central Bank. These activities served to help overcome the crisis, support failing financial institutions and restore the stability of the balance of payments. The 2008 crisis was widespread in scale; radical steps needed to be taken and huge financial resources put to use in order to attempt to repair the world economy. The scale of aid granted to financial institutions in order to overcome the crisis was unprecedented. According to estimates of the Bank for International Settlements, various aid packages, instruments and lines used in eleven countries between September 2008 and June 2009 (Austria, Canada, France, Germany Italy, Japan, the Netherlands, Spain, Switzerland, the United Kingdom, and the United States) totalled approximately EUR 5 trillion $^{16}$. In the face of such a major crisis, the IMF had to take appropriate steps to support countries in their hour of need. It should be noted that managing such huge resources and satisfying the need to recapitalise the economies of the countries in questions was a gargantuan challenge. The world's central banks, political decisionmakers as well as the IMF deliberated how to manage such huge sums in order to provide loans to these countries. In the final months of 2008 alone, the IMF granted loans (Stand-By Arrangements, SBA) totalling USD 48.6 billion (SDR 31.7 billion $^{17}$ ). On the other hand, in 2009, loans granted from the General Resources Account amounted to USD 36.6 billion (SDR 23.3 billion) ${ }^{18}$. In March 2009, the IMF Board of Governors presented

16 F. Panetta, T. Faeh, G. Grande, C. Ho, M. King, A. Levy, F. M. Signoretti, M. Taboga and A. Zaghini, BIS Papers No 48. An assessment of financial sector rescue programmes, https://www.bis.org/publ/bppdf/bispap48.pdf, p. 1. accessed on: 22.02.2018.

17 SDR (or XDR) - special drawing rights are arbitrary units of currency used by the IMF for settlements. The value of the SDR is based on a basket of five currencies (USD, CNY, EUR, JPY, GBP).

18 P. Gąsiorowski (ed.), op.cit., p. 38-40. 
a programme to reform the functioning of the IMF itself in order to adapt the then instruments of the IMF to the needs of the global economy in crisis. The reforms were undertaken in order to strengthen the ability of the IMF to prevent and resolve crises. Action was taken to improve the effectiveness of unconsolidated credit instruments to satisfy the needs of members whilst maintaining the appropriate level of security for the resources of the Fund. Amongst the planned reforms were the following: establishing Flexible Credit Line arrangements, the reform of Stand-By Arrangements, the simplification of the fund lending toolkit, doubling of access limits to $200 \%$ of quota on an annual basis and to a $600 \%$ of quota cumulative limit (previous limits permitted borrowers to access limits of $100 \%$ on an annual basis and $300 \%$ of quota cumulative limit ${ }^{19}$ ) as well as enhancing precautionary instruments ${ }^{20}$.

The increased loan activity of the IMF after the outbreak of the financial crisis and forecasted loan needs amongst member countries affected by the crisis forced the IMF to increase the upper limit of available loan resources whilst maintaining the Fund's financial liquidity. The IMF has resources of its own and borrowed resources ${ }^{21}$. These resources stem from payments from members, determined on the basis of that member country's share in the world economy. New members usually pay one quarter of their quota in the form of commonly accepted foreign currencies (for example, the dollar, euro, renminbi, yen, sterling) or special rights to draw the rest of the quota in their local currency. The IMF periodically reviews these shares and quotas, with the last one taking place in $2010^{22}$. This was the fourteenth review which ended in a decision to raise the quota payments ${ }^{23}$. This decision was taken by the Board of Governors ${ }^{24}$ in the form

19 B. Bernaś (ed.), Finanse międzynarodowe, Warsaw 2006, p. 57.

20 Public Information Notice: IMF Overhauls Nonconcessional Lending Facilities and Conditionality, https://www.imf.org/en/News/Articles/2015/09/28/04/53/pn0940, accessed on: 22.03.2018.

21 S. Naruszewicz, K. Czerewicz, Międzynarodowe instytucje finansowe wobec wyzwań współczesności [International financial institutions toward challenges of modernity], Białystok 2003, p. 23.

${ }^{22}$ Where the IMF Gets Its Money, http://www.imf.org/en/About/Factsheets/Wherethe-IMF-Gets-Its-Money, accessed on: 10.03.2018.

${ }^{23}$ Selected Decisions and Selected Documents of the IMF, Thirty-Ninth Issue, http:// bit.ly/priel-18-2-10, accessed on: 10.03.2018.

24 Board of Governors - the highest decision-making body of the IMF, consists of usually the minister of finance or the governor of the central bank. 
of Resolution No. 66-2 (adopted 15.12.2010). The Resolution also introduced changes to the IMF Executive Board ${ }^{25}$. A condition for changing the share of quotas in the IMF was the written consent of every member country which was affected by the raising of quotas and paying to the Fund the full amount of such an increase ${ }^{26}$. Furthermore, the increase in quotas was to be confirmed by the Executive Board who determined that members having not less than $70 \%$ of the total of quotas on 5.11 .2010 have consented in writing to the increases in their quotas and the adoption of the amendment set out in Attachment II of Resolution 66-2 as well as proposed amendments to the Board of Governors Resolution No. $63-2^{27}$. In order for the amendments to the Articles of Agreement of the IMF to be adopted, three-fifths of members, having eighty-five percent of the total voting power, must accept the proposed amendment ${ }^{28}$. The discussed amendment was adopted 26.1.2016 ${ }^{29}$, Poland ratified the Amendment via the Act of 29.6.2011 ${ }^{30}$. In accordance with the adopted amendment, member quotas increased from SDR 238.5 billion to SDR 477 billion $^{31}$.

Other than increasing the resources at the IMF's disposal, the change in the division and limit of quotas brought about a change in the structural division that particular countries had their share of votes reflecting their real place in the global economy ${ }^{32}$. Increasing quota size is one of the basic methods of increasing the resources at the disposal of the IMF, although the procedure for undertaking this is lengthy and requires the consent

25 Executive Board - responsible for conducting the day-to-day business of the IMF. It is composed of 24 Directors and the Managing Director.

${ }^{26}$ Point 2, Board of Governors Resolution No. 66-2 on the Fourteenth General Review of Quotas and Reform of the Executive Board, adopted 15.12.2010, https://www.imf.org/ external/selecteddecisions/description.aspx?decision=66-2.

27 Point 3, Board of Governors Resolution No. 66-2 on the Fourteenth General Review of Quotas and Reform of the Executive Board, adopted 15.12.2010, https://www.imf.org/external/selecteddecisions/description.aspx?decision=66-2.

28 Article XXVIII, Articles of Agreement of the IMF (M.P. of 13.05.2010).

29 Articles of Agreement of the International Monetary Fund, https://www.imf.org/ external/pubs/ft/aa/pdf/aa.pdf, accessed on: 23.02.2018.

30 Ustawa o ratyfikacji Poprawki do Umowy o Międzynarodowym Funduszu Walutowym dotyczącej reformy Rady Wykonawczej, przyjętej przez Radę Gubernatorów Międzynarodowego Funduszu Walutowego Rezolucją Nr 66-2 w dniu 15 grudnia 2010 r., O.J. 2011 No 178 Item 1055.

${ }^{31}$ IMF Quotas, http://www.imf.org/en/About/Factsheets/Sheets/2016/07/14/12/21/ IMF-Quotas, accessed on: 22.02.2018.

32 P. Gąsiorowski (ed.), op.cit., p. 51-52. 
of the Board of Governors, and then consent from each member country. The procedure of increasing quota size lasted six years. Had the IMF been forced to use only this mechanism, it would not have been able to react in time and come to the aid of those members affected by the financial crisis. For this reason, the IMF made use of another method of increasing resources via bilateral and multilateral loans ${ }^{33}$. Multilateral loans fall into two types: New Arrangements to Borrow (NAB) and General Arrangements to Borrow (GAB). NAB was first introduced in December 1998, whereas GAB began life in $1962^{34}$. Both Arrangements constitute the so-called "second line of defence" after the possibility of raising membership quotas and are most often used in the face of serious financial crises (with GAB resources used in 1998 to support Russia ${ }^{35}$ ). The parties to the series of agreements constituting NAB were 38 countries and institutions (for example, the National Bank of Poland). Within the series of actions undertaken after the outbreak of the global crisis in April 2009, the G20 agreed to an increase in the resources available to the IMF of even USD 500 billion, tripling the total loan amounts before the crisis to USD 250 billion. Furthermore, thanks to GAB, the IMF has at its disposal the additional currencies of the eleven countries participating in the Agreements. GAB can only be activated when an application for NAB is rejected by participants of NAB. The potential loan amount available to the IMF via GAB totals SDR 17 billion, and a further SDR 1.5 billion is available under the framework of a related loan agreement with Saudi Arabia ${ }^{36}$. The IMF also topped up its resources during the crisis with the help of bilateral loans. The International Monetary Fund signed a series of bilateral borrowing agreements in the years 2009-2010 in order to ensure it would be able to satisfy the financial needs of its members during the crisis. In 2012 following deeper problems during the crisis for the eurozone, it agreed upon another round of bilateral loans for a period of four years. In 2016 due to the continued uncertainty of the global economy, IMF members committed to maintain access to bilateral loans but amended in scope at

33 Where the IMF Gets Its Money, http://www.imf.org/en/About/Factsheets/Wherethe-IMF-Gets-Its-Money, accessed on: 23.02.2018.

34 S. Naruszewicz, K. Czerewicz, op.cit., p. 24-25.

35 Ibid., p. 26.

36 IMF Standing Borrowing Arrangements, https://www.imf.org/en/About/Factsheets/ Sheets/2016/08/05/17/55/IMF-Standing-Borrowing-Arrangements, accessed on: 24.02.2018. 
least until the end of $2019^{37}$. In the years 2009-2011, nineteen bilateral agreements were concluded as well as three agreements on the purchase of IMF obligations totalling SDR 234.5 billion (USD 362.5 billion) ${ }^{38}$. The eurozone states alone declared that they would sign bilateral loan agreements amounting to EUR 200 billion $^{39}$, which in reality materialised as a loan worth EUR 150 billion $^{40}$. In subsequent years, further discussions took place and efforts made to equip the IMF with additional resources in order to help countries affected by the crisis. In 2016 due to continued uncertainty in the global economy, the IMF Executive Board approved new frameworks for bilateral loans. These new frameworks allowed the IMF to temporarily make use of bilateral loans and avoid sudden drops in creditworthiness. These frameworks are defined in "Guidelines for Borrowing by the Fund", which is periodically updated by the IMF Executive Board from 1982. As of the 12.10.2017, forty member countries had agreed to conclude bilateral loan agreements amounting to SDR 319 billion (USD 450 billion) ${ }^{41}$.

The IMF also possesses gold reserves, which were amassed from payments by member countries. The gold reserves amounted to 2,914.1 metric tons ${ }^{42}$. The IMF is officially one of the world's largest holders of gold, in fact ranked third in the world ${ }^{43}$. The IMF is able to sell gold in order to increase its resources, which can serve to help member countries. The Articles of Agreement of the IMF strictly define the rules and conditions for making use of their gold reserves. Consent for the sale of gold must

37 Where the IMF Gets Its Money, http://www.imf.org/en/About/Factsheets/Wherethe-IMF-Gets-Its-Money, accessed on: 23.02.2018.

${ }^{38}$ P. Gąsiorowski (ed.), op. cit., p. 51.

39 Statement by the Euro Area Heads of State or Government, https://www.consilium. europa.eu/uedocs/cms_data/docs/pressdata/en/ec/126658.pdf, accessed on: 25.02.2018, p. 6.

40 EU Finance Ministers statement on IMF resources, http://www.consilium.europa. eu/uedocs/cms_Data/docs/pressdata/en/ecofin/127062.pdf, p.1.

${ }^{41}$ IMF Bilateral Borrowing, http://www.imf.org/en/About/Factsheets/ Sheets/2016/10/20/IMF-Bilateral-Borrowing, accessed on: 24.02.2018.

42 Where the IMF Gets Its Money, http://www.imf.org/en/About/Factsheets/Wherethe-IMF-Gets-Its-Money, accessed on: 23.02.2018.

43 E. Polak, Międzynarodowe organizacje gospodarcze wobec kryzysu finansowego - na przykładzie MFW, [International economic organizations with regard to the financial crisis - the example of the IMF] [in:] 'Nierówności społeczne a wzrost gospodarczy' [Social inequalities and economic growth], Zeszyt 30, Uniwersytet Rzeszowski, Rzeszów 2013, p. 25-39. 
be expressed by $85 \%$ of the general votes allotted to all members ${ }^{44}$. In December 2010, the IMF concluded a transaction for the sale of 403.3 metric tons of gold. This limited sale was undertaken under great safeguards to ensure no disturbances on the market. The IMF made SDR 4.4 billion from the sale. A part of this money is used to subsidise countries with lower income on a preferential basis ${ }^{45}$.

Additionally, the IMF took action to adapt its loan instruments to the current situation. Changes were made to the rules under which Stand-by Agreements (SBA) were used. Not only could countries with real problems take advantage of SBAs but also countries in danger of having financial problems. Furthermore, the frequency of periodic reviews was reduced, and the approach to concluding agreements became more personalised and suited to the potential needs of member countries. Further modifications concerned the Extended Facility Fund (EFF), which was addressed to countries experiencing lengthy problems in the stability of their balance of payments. The term of repayment for EFFs was extended from three to four years. What is more, the International Monetary Fund established two new instruments: the Flexible Credit Line (FCL) and Precautionary Credit Line (PCL). The latter was replaced by a modified instrument in 2011, namely the Precautionary and Liquidity Line (PLL). Both instruments are precautionary in nature ${ }^{46}$. One of the beneficiaries of the FCL was Poland, which had a credit line made available to it for the first time in 2009. It was then extended by further arrangements until Poland prematurely resigned from the instrument in $2017^{47}$. Additionally, two instruments that were used to deal with extraordinary circumstances were replaced by one instrument, that is the Emergency Natural Disaster Assistance and Emergency Post-Conflict Assistance made way for the Rapid Financing Instrument. The latter can be used to provide speedy aid to members hit by natural disaster, the shock of a sudden change in prices or fighting the consequences of an ongoing or recently-finished conflict. From the point of the IMF, this instrument is vital in that it does not need

44 Article V, exc. 12, Articles of Agreement of the IMF (M.P. of 13.05.2010).

45 Where the IMF Gets Its Money, http://www.imf.org/en/About/Factsheets/Wherethe-IMF-Gets-Its-Money, accessed on: 23.02.2018.

46 P. Gąsiorowski (editor), op. cit., p. 23-27.

47 Poland Ends the Two-Year EUR 8.24 Billion Flexible Credit Line Arrangement with the IMF, http://www.imf.org/en/News/Articles/2017/11/02/pr17418-poland-ends-thetwo-year-flexible-credit-line-arrangement-with-the-imf, accessed on: 24.02.2018. 
a prepared and realised repair programme by the borrower, which is often a key condition in receiving aid $^{48}$.

Action was taken to modify existing loan instruments and establish new ones in order to guarantee that the IMF have the possibility of reacting quickly as the global financial crisis posed new challenges to the international community and individual countries. The financial crisis spread like wildfire and caused violent and irrevocable changes to financial markets all over the world. In the face of such a depression, it was essential to react quickly and engage hitherto unheard of resources in order to save strategically significant financial institutions for the good of the economies of countries and regions.

As well as actions to improve its financial capabilities, the IMF also undertook work to modify and adapt its supervisory instruments and expert operations to the global situation. Even before the global financial crisis hit, there were signals that the instruments used by the IMF were not up to the challenge of identifying financial crises. A report published by the United States General Accounting Office claimed that the IMF had predicted a mere fifteen out of 134 recessions in the years $1991-2001^{49}$. Following the outbreak of the financial crisis and further accusations made about the IMF, a series of initiatives were introduced in order to improve the existing supervisory operations and establish new mechanisms. One of the major changes was the introduction of a new report entitled "Fiscal Monitor" in 2009. What is more from 2011 there have been reports analysing the possibility of spill over, and reports evaluating any possibility of systemic risk. In terms of modifying already existing instruments, World Economic Outlook was extended to include spill over phenomena. Also, the reviews undertaken under Article IV of the Articles of Agreement of the IMF were extended with reviews of the financial sector ${ }^{50}$.

48 The IMF's Rapid Financing Instrument (RFI), https://www.imf.org/en/About/ Factsheets/Sheets/2016/08/02/19/55/Rapid-Financing-Instrument, accessed on: 24.02.2018.

49 The IMF Cannot Predict a Crisis, https://www.pb.pl/mfw-nie-potrafi-przewidzieckryzysu-164103, accessed on: 23.02.2018.

50 P. Gąsiorowski (editor), op.cit., p. 12 


\section{Crisis in Greece}

The Greek financial crisis was a consequence of the global financial crisis caused by the collapse of Lehman Brothers in 2008 in the US. The crisis quickly spread to many other countries including the European Union where it had a great impact. The interconnected economies of the eurozone states were particularly susceptible to crisis and infection. Due to its connected network of economies, structures, institutions and politics, the European Union was extremely sensitive to the effects of the crisis. The infection of one state would bring negative consequences to other member states. Greece was particularly affected by the crisis and it received tremendous amounts of international aid. In the case of Greece, a great many problems which had been plaguing the country for years were uncovered. These included problems with regulating financial obligations, debt and problems with economic reform. Due to the sheer scale of aid received from particular countries and international institutions, the case of Greece deserves discussion.

Greece joined the eurozone in 2001 after long negotiations and much effort from the Greek government to enter the monetary union ${ }^{51}$. The financial crisis which affected the states of the eurozone first hit Greece at the turn of 2009, and manifested itself with Greece having trouble settling its foreign financial obligations. In the coming months, Ireland, Spain, Portugal and Italy all had problems with their budget deficit ${ }^{52}$. The crisis in Greece ignited speculation and discussion on whether Greece should even be part of the eurozone and if the decision to accept Greece to the monetary union was economically-motivated and whether the economic data presented by Greece were reliable. Greece was in a difficult economic situation even before the financial crisis. Before Greek parliamentary elections in 2009, the issue of the need to improve the data submitted to Eurostat was raised, which actually happened after the elections. In accordance with the data, it appeared that the deficit in the GG sector

51 K. Rojowski, Kryzys finansowy w Grecji - przyczyny, obecna sytuacja i skutki [Financial crisis in Greece], [in:] Analiza Unia Europejska.org, no 1[17]/2015, p. 3-5.

52 E. Cziomer, Polityczno-prawne aspekty kryzysu zadłużenia strefy Euro Unii Europejskiej [Political and legal aspects of the debt crisis in the Euro zone of the European Union], 'Annales UMCS' 2012, sectio K, vol. XIX, p.13. 
was not the previously presented $3.7 \%$ but $12 \%^{53}$. Greece was struggling with public sector borrowing and in 2004 the national debt amounted to $97.4 \%$ of the $\mathrm{GDP}^{54}$. Greece also had problems with an ineffective tax system, a bloated social security system, an inflated benefit system and an excessive bonus system. This negative situation only intensified the problem of inflation ${ }^{55}$. Additionally, Greece had been struggling with an imbalance between import and export; between the years 1976 and 1991 the Greek trade deficit soared from USD 7 billion to USD 20 billion $^{56}$. A consequence of the exposed manipulation of economic data provided by Greece to Eurostat in 2009 was the lowering of Greece's credit rating by all the credit rating agencies; Greece's creditworthiness plummeted, its assets on the financial markets dropped, Greek obligations were no longer attractive investment prospects, and the influx of investments into Greece came to a grinding halt. Greece's financial commitments began to stack up (with the government's commitments to the national banking sector amounting to EUR 40 billion). All these negative phenomena only pushed Greece further into recession ${ }^{57}$. The Greek crisis manifested itself by increasing national debt, and problems by the Greek government in meeting their financial commitments. In the subsequent year, the government of Greece and EU institutions attempted to introduce actions which would halt these negative phenomena and stop the drop in the price of Greek obligations and credit ratings ${ }^{58}$. The actions undertaken in the first phase of the Greek crisis did not bring the expected benefits and did not stop the recession. For that reason, it was deemed necessary to introduce

53 Greek Crisis - Genesis and Consequences. Document Supplementing the Strategic Framework for the National Plan for Introducing the Euro, http://bit.ly/priel-18-2-11, accessed on: 22.02.2018, p. 3.

54 C. Simitis, The European Debt Crisis: The Greek case, Oxford 2016, p. 6.

55 M. du Vall, Droga Grecji do Unii Gospodarczo-Walutowej. Zarys Problematyki [Greece's way to the Economic and Monetary Union. An outline of the problem], 'Państwo i Społeczeństwo' 2011, vol.(XI), no 4 p. 114.

56 Onno Kuik, Frans H. Oosterhuis, Lessons from the Southern Enlargement of the EU for the Environmental Dimensions of Eastern Enlargement, in Particular for Poland (July 2001), FEEM Working Paper No. 59.2001, p. 6.

57 Greek Crisis - Genesis and Consequences. Document Supplementing the Strategic Framework for the National Plan for Introducing the Euro, http://bit.ly/priel-18-2-11, accessed on: 22.02.2018, p. 3, 14-17.

58 The economic adjustment programme for Greece, http://bit.ly/priel-18-2-12, accessed on: 27.02.2018, p. 13. 
intervention actions and involve much greater financial resources in order to cover Greece's obligations.

\section{Aid Programmes for Greece}

Greece's financial difficulties were so great that both the European Union and the International Monetary Fund had to collectively take unprecedented actions to deal with them. The EU needed to make amendments to the Treaty Treaty on the Functioning of the European Union in order to introduce effective mechanisms to safeguard the financial stability of the eurozone ${ }^{59}$. A tremendous problem was primarily the unwillingness of private investors to provide additional financing to Greece, which meant that the use of public resources became indispensable ${ }^{60}$. It was also necessary to coordinate the financial aid received from the IMF and EU. Not only did the actions of international organisations require huge financial resources but also the preparation of a plan of political, fiscal, social and existing debt restructuring reforms. When discussing the support provided to Greece by the IMF, we should also consider the initiatives taken by the European Union. Furthermore, it is worth highlighting that the evaluation of the reform and repair programmes undertaken by Greece was also undertaken jointly by EU and IMF representatives.

The aid afforded Greece was divided into three programmes, which were activated in three stages whilst Greece introduced changes and came out of the crisis. The first aid programme was activated in May 2010 and was preceded by a series of consultations with the IMF and EU. From the beginning of 2010, the IMF worked closely with the EU watching the actions taken by both Greece and the EU offering its readiness to offer expertise and all other forms of support necessary for escaping the crisis ${ }^{61}$. The size of the loans granted to Greece and the formula under which financing took place was preceded by visits from representatives of the European Commission (EC), the European Central Bank (ECB) and

59 European Council Decision of 25 March 2011 amending Article 136 of the Treaty on the Functioning of the European Union with regard to a stability mechanism for Member States whose currency is the euro, 6.04.2011, OJ, L 91/1, p. 1-2.

${ }^{60}$ Bringing Greece back to Growth, http://bit.ly/priel-18-2-13, accessed on: 25.02.2018.

61 Press Release: IMF Statement on Greece, http://bit.ly/priel-18-2-14, accessed on: 25.02.2018. 
the IMF between 21.4.2010 and 3.5.2010. The joint mission of EU institutions and IMF (the so-called 'Troika') evaluated the state of the Greek economy and then cooperated closely with the Greek government which prepared a plan of reform ${ }^{62}$. The first aid programme for Greece comprised a EUR 80 billion loan within the framework of bilateral loans from eurozone member states. That amount decreased following the exit of Portugal, Slovakia and Ireland from the programme. Additionally, the IMF offered a loan of EUR 30 billion $^{63}$. The first aid programme for Greece was officially announced on 2 May $2010^{64}$. Greece would in total receive EUR 110 billion over three years as part of a financial aid programme. In a joint statement released on 2.5.2010 the EU Commissioner for Economic and Monetary Affairs and the Euro Olli Rehn and Managing Director of the IMF Dominique StraussKahn highlighted that they fully endorse the programme of reform laid out by the Greek government and, furthermore, the aid granted to Greek by the EU and IMF is an unprecedented event. They also highlighted the fact that the aid afforded Greece would support the entire eurozone as well as all of Europe ${ }^{65}$. On 9.5.2010, the Executive Board of the IMF consented to grant a loan to Greece of EUR 30 billion. These resources were made available within the framework of SBA in order for the Greek government to introduce economic reforms in order to overcome the crisis. The loans, in accordance with the programme coordinated by the ECB, EC and the IMF, were planned for three years ${ }^{66}$.

SBAs are loan instruments offered by the IMF to countries affected by short-term problems or potential problems with maintaining their balance of payments. The resources made available by the Fund gave these countries an opportunity to introduce necessary reforms to re-dress the imbalance

62 The Economic Adjustment Programme for Greece, http://bit.ly/priel-18-2-12, accessed on: 25.02.2018, p. 3

63 Financial Assistance Programmes, http://bit.ly/priel-18-2-15, accessed on: 25.02.2018.

64 Statement of President Barroso on Greece, http://europa.eu/rapid/press-release_IP10-485_en.htm?locale=en, accessed on: 25.02.2018.

65 Press Release: Joint Statement on Greece by EU Commissioner Olli Rehn and IMF Managing Director Dominique Strauss-Kahn, http://www.imf.org/en/News/Articles/ 2015/09/14/01/49/pr10177, accessed on: 25.02.2018.

66 Press Release: IMF Executive Board Approves $€ 30$ Billion Stand-By Arrangement for Greece http://www.imf.org/en/News/Articles/2015/09/14/01/49/pr10187, accessed on: 10.03.2018. 
and maintain economic stability and economic growth ${ }^{67}$. The resources made available via SBA were paid out in tranches ${ }^{68}$. The payment of subsequent tranches is dependent on the realisation of the adaptive programme prepared by the country in question in cooperation with the $\mathrm{IMF}^{69}$. In the case of joint action undertaken together with the EU, the adaptive plan as well as its evaluation was undertaken by joint representatives of the ECB, EC, and IMF. In accordance with the adopted arrangements and the urgent need for financial aid, the EU and IMF took steps whereby some of the declared financial resources would be promptly transferred to Greece. Within the framework of the SBA, EUR 5.5 billion was promptly made available, with EUR 10 billion to be paid by the end of 2010. In accordance with the declarations made, the Greek government was obliged to take action in order to attain three primary goals: (i) the restoration of confidence and fiscal stability; (ii) the restoration of competition, and (iii) the protection of the stability of the financial sector ${ }^{70}$. The established goals and their realisation were constantly monitored by representatives of the European Commission, European Central Bank and International Monetary Fund. The representatives took part in missions to Athens where they analysed the progress of reform, plans and also served as consultants. The first of such reviews took place between 26.7.2010 and 5.8.2010 ${ }^{71}$. The participants of the mission all came to the conclusion that the reforms undertaken by the Greek government were heading in the right direction, which opened the door for the next tranche of payments ${ }^{72}$. The second review mission in the framework of the first aid programme for Greece took place between 14.10.2010 and 23.10.2010. Again, the reforms were rated positively ${ }^{73}$. The next visit by representatives of the ECB, EC and IMF took

67 IMF Lending, http://www.imf.org/en/About/Factsheets/IMF-Lending, accessed on: 10.03 .2018 .

68 S. Naruszewicz, K. Czerewacz, op.cit., p. 28.

69 E. Ambukita, K. Munyama, Międzynarodowe instytucje finansowe $w$ Polsce $w$ okresie transformacji [International financial institutions in Poland in the period of transformation], Poznań 2002, pp. 14-15.

70 Press Release: IMF Executive Board Approves $€ 30$ Billion Stand-By Arrangement for Greece, http://bit.ly/priel-18-2-18, accessed on: 10.03.2018.

71 The Economic Adjustment Programme for Greece. First Review, Summer 2010, http:// bit.ly/priel-18-2-16, accessed on: 10.03.2018, p. 1.

72 Statement by the EC, ECB, and IMF on the First Review Mission to Greece, http://bit. ly/priel-18-2-17, accessed on: 10.03.2018.

73 Statement by the EC, ECB, and IMF on their Second Review Mission to Greece, http:// bit.ly/priel-18-2-19, accessed on: 14.03.218. 
place 27.1.2011-11.2.2011. The positive review was the basis for a subsequent tranche payout from the IMF of EU 4.1 billion $^{74}$. The fourth mission (June 2011) once again positively assessed Greece's efforts in implementing reforms and adopted legal regulations concerning the modernisation of the public administration, health sector reforms, improvements in the functioning of the labour market, removing barriers when establishing and doing business as well as liberalising the transport and energy sectors ${ }^{75}$. The fifth mission (October 2011) continued in the series of positive assessments for the Greek government's reforms and its direction of economic changes, however, it stressed the need for obtaining more financial resources essential for the Greek economy to bounce back. The mission's assessment once again opened the door for the payment of the next tranche, however, it highlighted the fact that the country's economy was not as healthy as initially believed, and political uncertainty continued to hinder the rebuilding of investor confidence in Greece ${ }^{76}$. In summary, within the framework of the first aid programme, the IMF provided Greece with EUR 20.1 billion in six tranches, not the originally planned sum of EUR 30 billion $^{77}$.

On 14.3.2012, the Greek government decided to resign from taking further advantage of any resources made available to it via SBA. This took place following arrangements made by Greece, IMF, EC and ECB within the second aid programme for Greece. The decision to make the second programme analogous to the first was taken following missions by representatives of the IMF, EC and ECB in Athens between 11.1.2012 and 9.2.2012 ${ }^{78}$. The realisation of the second programme was planned for the years 2012-2014, with the aim being to provide the Greeks with additional monetary resources so they could continue with their planned reforms, strengthen the economy, fight unemployment, and restore

74 Statement by the EC, ECB and IMF on the Third Review Mission to Greece, http:// europa.eu/rapid/press-release_MEMO-11-119_en.htm, accessed on: 14.03.2018.

75 Statement by the European Commission, the ECB and IMF on the Fourth Review Mission to Greece, http://europa.eu/rapid/press-release_MEMO-11-372_en.htm, accessed on: 14.03.2018.

${ }^{76}$ Statement by the European Commission, the ECB and IMF on the Fifth Review Mission to Greece, http://europa.eu/rapid/press-release_MEMO-11-684_en.htm, accessed on: 14.03.2018.

77 The Economic Adjustment Programme for Greece Fifth Review - October 2011, http:// bit.ly/priel-18-2-23, accessed on: 10.03.2018, p.5.

78 The Second Economic Adjustment Programme for Greece, March 2012, http://bit.ly/ priel-18-2-24, p. 1. 
the confidence of investors. The eurozone states and the IMF were once again engaged in the realisation of the second aid programme. However, a modified instrument was taken advantage of for that purpose. For the first time ever, the European Union made the financial resources available via the European Financial Stability Facility (EFSF), whereas the IMF made loans available in the form of the Extend Fund Facility (EFF). The planned financial support for Greece as part of the second programme totalled EUR 164.5 billion. The plan also included attempts at gaining private sources of funding for Greece ${ }^{79}$.

Within the framework of the new loan instrument, the IMF provided Greece with EUR 28 billion of which EUR 1.65 million was handed over without delay after the decision to award the loan was taken. The decision was taken by the Executive Board of the IMF on 15.3.2012. The loan would be paid to Greece in tranches over a period of four years ${ }^{80}$. Those SBA funds that were unused were cancelled ${ }^{81}$. The EFF is used for mid-term problems that states have with their balance of payments, the length of the credit period and when the payment of obligations is longer than that of the SBA. The EFF is a support for countries undertaking structural reforms. It was established in order to help countries who have serious problems making payments due to structural issues or having problems with slow economic growth and poor balance of payments ${ }^{82}$.

This aid programme was realised analogically to the first. Representative of the ECB, the EC and IMF undertook periodic reviews (five in total), upon which subsequent tranches of the loan were granted. Four of the reviews were positive, whereas the fifth review ended with no agreement reached with the Greek government ${ }^{83}$. The situation in Greece began to change at the end of 2014, and in February 2015 the Greek government applied for an extension to the aid programme. After presenting their arguments to the representative of the EC and IMF, it was

79 Financial Assistance to Greece, http://bit.ly/priel-18-2-20, accessed on: 12.03.2018.

80 Press Release: IMF Executive Board Approves €28 Billion Arrangement Under Extended Fund Facility for Greece, http://bit.ly/priel-18-2-22, accessed on: 12.03.2018.

81 IMF Survey: IMF Board Approves €28 Billion Loan for Greece, http://bit.ly/ priel-18-2-21, accessed on: 12.03.2018.

82 IMF Extended Fund Facility (EFF), http://www.imf.org/en/About/Factsheets/ Sheets/2016/08/01/20/56/Extended-Fund-Facility, accessed 12.03.2018.

83 Financial Assistance to Greece, http://bit.ly/priel-18-2-20, accessed on: 12.03.2018. 
decided that the programme would be extended to June $2015^{84}$. The IMF did not receive payment of a subsequent tranche of their loan which was due on 30.6.2015. However, Greece motioned to the IMF for an extension to the period of repayment of their obligations ${ }^{85}$. All arrears to the IMF were paid in full on 20.7.2015 giving Greece the chance to receive further support ${ }^{86}$.

The third aid programme for Greece was accepted in August 2015 and is planned to last until 20.8.2018 ${ }^{87}$. Negotiations on a new aid programme were difficult in that from July 2015 a referendum took place in Greece in which citizens had a say in whether they wanted to continue cooperation with the EU and IMF in terms of further loans ${ }^{88}$. The attendance at referndum was $62.5 \%$. Over $61 \%$ of voters was against the further financial assistance from EU and IMF, but the result of the referendum was not treated as binding by the government ${ }^{89}$. The third aid programme for Greece came into effect on 19.8.2015. As part of the European Stability Mechanism (ESM), Greece was to receive EUR 86 billion. As with previous programmes, the funds would be paid out in tranches with each tranche dependant on the positive opinion of the audit mission visiting Athens ${ }^{90}$. IMF involvement followed relatively late due to the fact that the funds were awarded in the form of an SBA on 20.7.2017, amounting to EUR 1.6 billion. The programme expires on $31.8 .2018^{91}$. The awarding of funds

84 Overview of European Issues, February 2015, http://www.nbp.pl/publikacje/ pse/2015_02_pse.pdf, accessed on: 14.03.2018, p. 19-20.

${ }^{85}$ Press Release: Statement by the IMF on Greece, No. 15/310, http://www.imf.org/en/ News/Articles/2015/09/14/01/49/pr15310, accessed on: 14.03.2018.

${ }^{86}$ Press Release: Statement by the IMF on Greece, No. 15/344, http://www.imf.org/en/ News/Articles/2015/09/14/01/49/pr15344, accessed on: 14.03.2018.

87 Greece: the Third Economic Adjustment Programme, http://bit.ly/priel-18-2-25, accessed on: 14.03.2018.

${ }^{88}$ Merkel and Hollande: There is Little Time Left. Tsipras Needs to Make a Serious Proposal, http://www.newsweek.pl/swiat/grecy-odrzucili-w-referendum-warunki-zagranicznejpomocy,artykuly,366271,1.html, accessed on: 14.03.2018.

89 P. Wiśniewska, K., Stolarek, Europejska polityka Grecji [European Policy of Greece], 'ETE Working Paper' 2016, vol. 2, no 4, p. 9-12.

90 Greece: the Third Economic Adjustment Programme, http://www.consilium.europa. eu/en/policies/financial-assistance-eurozone-members/greece-programme/, accessed: on 14.03.2018.

91 IMF Executive Board Approves in Principle €1.6 Billion Stand-By Arrangement for Greece, http://www.imf.org/en/News/Articles/2017/07/20/pr17294-greece-imf-executive-boardapproves-in-principle-stand-by-arrangement, accessed on: 14.03.2018. 
was only possible once a consensus had been reached between the Greek government and the visiting experts of the IMF, EC, ECB and the EMS regarding the direction of the planned reforms and steps taken ${ }^{92}$. According to the information presented in an IMF statement, the decision was taken after partially rebuilding confidence in Greece following a shortterm crisis in solvency in relation to the IMF in 2015 as well the positive opinion on the continued direction of reform. What is more, Greece saw slight economic growth in the first quarter of 2017. The IMF expected a continuation of the structural reforms required for the liberalisation of its economy and participation in the eurozone in the long-term. These activities were also to constitute the framework for Greece's European partners to ensure a reduction in debt in order to restore balance in Greek debt. Within the area of fiscal policy, the action taken by Greece aimed to restore balance to the budget regarding policies aiding growth and eliminating social exclusion. A further important element in the Fund's assessment was the continuation of the package of income tax reforms and the pension system aiming to limit the uniquely generous tax exemptions for the middle classes and the incomparably high expenses of pensioners. The reforms of the financial sector were supposed to be directed at created the conditions for coping with the high dangers of loans through strengthening and implementing legal frameworks for restructuring debt. As well as maintaining fundamental reforms of the labour market in the period covered by the programme, the programme also supported reforming collective redundancies and stages of introducing ongoing reforms supporting competition and liberalising Sunday trading and selected closed professions, and easing investment. The final key element needed for restoring the financial stability of Greece in the long-term is debt reduction. Further discussion on a strategy based on realistic assumptions and an extended scope of debt reduction in order to restore balance in the national debt of Greece was also necessary ${ }^{93}$.

The financial aid packages received from the IMF and the suggested directions of reform are strictly coordinated by the IMF and EU. Furthermore, as highlighted by point 8 of the introduction and article 13 of the Treaty

92 Statement by the EC, ESM, ECB and IMF on negotiations with Greece, http://bit.ly/ priel-18-2-26, accessed on: 14.03.2018.

93 IMF Executive Board Approves in Principle $€ 1.6$ Billion Stand-By Arrangement for Greece, http://www.imf.org/en/News/Articles/2017/07/20/pr17294-greece-imf-executive-boardapproves-in-principle-stand-by-arrangement, accessed on: 14.03.2018. 
Establishing the European Stability Mechanism (ESM), these two aforementioned institutions will work closely together. The involvement of the IMF includes not only financial involvement by also expert advice. A general rule also highlighted is the fact that countries applying for aid from the ESM should also apply for aid from the $\mathrm{IMF}^{94}$.

\section{Summary}

The financial crisis in Greece initially appeared to be impossible to overcome. In undertaking joint and coordinated action, the European Union and International Monetary Fund were able to collect the necessary resources. Not only did Greece make use of the joint aid mechanisms, but also Portugal and Ireland ${ }^{95}$. It was only through the participation of such large international organisations that such financial resources could be gathered; individual states or in fact the EU or IMF alone would not have been able to manage such resources.

The key element for Greece in escaping the financial crisis was that of financial resources, which it could make use of immediately in order to meet its necessary financial commitments and also cover the costs of introducing key reforms. Financial aid is strictly connected to support from experts with the participation of the EU and IMF during the development and implementation of reforms. In essence, the implementation by Greece of the recommendations of experts determined the possibility of receiving subsequent loan tranches, either from the IMF or EU; the Greek government has very limited possibilities in taking independent action or implementing internal reforms. The Greek situation demonstrates the dangers of excessive (unbalanced) national debt and how it can affect a state's very independence.

It needs to be underlined that the issues of financial obligations of states in relation to the IMF and the scope of the IMF's competences were not the subject of judgment or award of international courts or arbitration. The literature points out the ruling EM Ltd $v$ Republic of Argentina as

94 Treaty Establishing the European Stability Mechanism, https://www.esm.europa.eu/ sites/default/files/20150203_-_esm_treaty_-_en_1.pdf, accessed on: 14.03.2018 .

95 Aim Programme for Greece, Ireland and Portugal - situation as of August 2011, https:// www.nbp.pl/publikacje/integracja_europejska/programy_pomocowe.pdf, accessed on: 14.03.2018, p. 1. 
important for understanding the nature of the financial obligation between the IMF and the member states ${ }^{96}$. Nevertheless, the subject of the dispute and the factual situation do not allow make analogy to the situation of support for Greece during financial crisis and after as well. It should be emphasized, that in this ruling it was clearly indicated that obligations towards the IMF are public, not private.

The EU Court of Justice (CJEU) has not referred in its rulings to the essence of cooperation between EU institutions and the IMF in order to support countries affected by the crisis. The CJEU in matters pertaining to the powers and principles of supporting countries affected by the crisis, e.g. joined Cases C-105/15 P to C-109/15 P ${ }^{97}$ and Case C-62/14 ${ }^{98}$, it recalled the provisions of article 13 the Treaty Establishing the European Stability Mechanism, indicating the necessary condition of cooperation with the IMF in the field of making decisions on granting support and conditions for this support (item 4. C-62).

From the beginning of the global financial crisis, the IMF demonstrated through its actions that it continues to be a key organisation effecting financial global stability and supporting countries who have problems with balance of payments. In order to support Greece, the IMF utilised instruments that had been in existence almost from the inception of the Fund over seventy years ago. The one factor, as mentioned at the beginning of the article, that the IMF did undertake was the modification of already existing instruments. However, these modifications were merely to adapt the instruments to the situation in question and did not affect the nature, form or characteristics of the instruments themselves.

The effectiveness of the mechanisms within the IMF related to the possibility of recapitalising the IMF and acquiring additional resources necessary for the providing loans to countries should be highlighted. The IMF used the possibility of selling the gold it owned and made use of bilateral and multilateral loans in the form of General Agreements to Borrow (GAB) and New Agreements to Borrow (NAB).

96 R.S. J. Martha, The financial obligation in international law, Oxford 2015, p. 54-55.

97 Judgment of the Court (Grand Chamber) of 20.09.2016, Ledra Advertising Ltd and Others v European Commission and European Central Bank (ECB), Joined Cases C-8/15 P to C-10/15 P.

98 Judgment of the Court (Grand Chamber) of 16.07.2015, Peter Gauweiler and Others v Deutscher Bundestag, Case C-62/14. 
The global financial crisis as well as the Greek crisis demonstrated how the mechanisms, instruments and institutions hitherto utilised by the IMF were practically applied and instruments necessary in overcoming unprecedented (from the establishment of the IMF) problems related to the solvency of countries.

\section{Bibliography}

1. Bernaś B. (ed), Finanse międzynarodowe, Warsaw 2006.

2. Cziomer E., Polityczno-prawne aspekty kryzysu zadłużenia strefy Euro Unii Europejskiej, 'Annales UMCS' 2012, Sectio K, vol. XIX.

3. Gąsiorowski P. (ed.), Frankiewicz D., Grotte M., Życieńska A., Międzynarodowy Fundusz Walutowy $w$ reakcji na światowy kryzys finansowy i gospodarczy, available at: https://www.nbp.pl/badania/seminaria/20xi2012.pdf .

4. Greece: the Third Economic Adjustment Programme, available at: http://www. consilium.europa.eu/en/policies/financial-assistance-eurozone-members/ greece-programme/.

5. Greek Crisis - Genesis and Consequences. Document Supplementing the Strategic Framework for the National Plan for Introducing the Euro, available at http:// www.mf.gov.pl/documents/764034/1432744/6_ramy_dok_uzupelniajacy_ Grecja.pdf.

6. Kuik, O., Oosterhuis, F. H., Lessons from the Southern Enlargement of the EU for the Environmental Dimensions of Eastern Enlargement, in Particular for Poland (July 2001), 'FEEM Working Paper' 2001, no 59.

7. Martha R.S. J., The financial obligation in international law, Oxfrord 2015.

8. Naruszewicz S., Czerewicz K., Międzynarodowe instytucje finansowe wobec wyzwań wspótczesności, Białystok 2003.

9. Panetta F., Faeh T., Grande G., Ho C., King M., Levy A., Signoretti F. M., Taboga M. and Zaghini A., BIS Papers No 48. An assessment of financial sector rescue programmes, available at https://www.bis.org/publ/bppdf/ bispap48.pdf.

10. Polak E., Międzynarodowe organizacje gospodarcze wobec kryzysu finansowego - na przykładzie MFW, [in:] 'Nierówności społeczne a wzrost gospodarczy', Issue 30, Uniwersytet Rzeszowski, Rzeszów 2013.

11. Rojowski K., Kryzys finansowy w Grecji - przyczyny, obecna sytuacja i skutki, [in:] Analiza UniaEuropejska.org, No. 1[17]/2015.

12. Simitis C., The European Debt Crisis: The Greek case, Oxford 2016.

13. du Vall M., Droga Grecji do Unii Gospodarczo-Walutowej. Zarys Problematyki, [in:] Państwo i Społeczeństwo 2011 (XI) nr 4.

14. Wiśniewska P., Stolarek K., Europejska polityka Grecji, 'ETE Working Paper' 2016, vol. 2, no 4. 